\title{
A Review of Factors Affecting Customer Loyalty in Banking Industry
}

\author{
Mohammed Arman Ali ${ }^{1}$, Valliappan Raju ${ }^{2}$ \\ Post Graduate Center, Limkokwing University of Creative Technology, Malaysia ${ }^{1,2}$
}

\begin{abstract}
In the past few years, the term "Customer loyalty" has become a real trend in almost all business areas in which the client has an important role: banking, retail, telecommunications, manufacturing, automotive, insurance et al. Every business understands that the more customers attracts and the more existing customers retains financial results can improve, and the organization continues its work. In this context, identifying the factors that contribute to defining customer loyalty is very important. The present paper identifies the variables that contribute in defining customer loyalty within the banking system.
\end{abstract}

Keywords: Customer loyalty, Customer satisfaction, Customer retention, Customer Confidence

\section{INTRODUCTION}

Customer Loyalty means that the customers will repurchase the same brand merchandise or services consistently in the future without affected by the situation that could lead to shifting behaviour [1]. As cited in Bowen and Chen (2015), mixed behavioural dimension and attitudinal dimension that consider as composite measurement, is applied to measure customer loyalty. Measurement considers consistent which repetitious behaviour as a sign of loyalty. The dimensions that are attitudinal utilise information to reflect the emotional and psychological attachment inherent in loyalty and concerned with the sense of loyalty and allegiance based on Shrestha (2014). Besides, there's an ongoing increase in customers' expectation in the present condition of increased global competition [3].

\section{LITERATURE REVIEW}

Customer loyalty Customer loyalty is a very important concept for many bankers. Arguably why so many bankers are struggling with developing, implementing and measuring loyalty programs to customers is that there is consensus among bankers about what behaviours constitute customer loyalty and how best practices can encourage these behaviours [7]. The lack of agreement between the bankers on the variables that constitute customer loyalty determines that a series of customer loyalty programs do not often succeed and are not productive. In addition, many bankers from banking retail still confuse customer loyalty with three distinct concepts, but closely related: customer satisfaction, customer retention and customer confidence [4]. In the studies, [5] [4], these four concepts, loyalty, satisfaction, retention and customer confidence covers:

- Customer loyalty: Adhesion demonstration of a client to an institution / trader, despite the occasional error.

- Customer satisfaction: Customer perception of the needs, wishes and expectations regarding products and services which have been met. Customer satisfaction is not a guarantee of retention or loyalty.

- Customer retention: the organization's ability to keep existing customers over time. Unlike customer loyalty and customer satisfaction, which measures aspects of the relationship in terms of the customer, customer retention is a direct measure of the institution's capacity to maintain relationships with customers over a long period of time.

- Customer Confidence: banks rely on trust. Confidence comes first. Customers who have this state of confidence in banks, never drift from the products and services offered by the bank. They trust and use them and do not give them up.

Table1: Definition of Customer Loyalty

\begin{tabular}{|l|l|}
\hline \multicolumn{1}{|c|}{ Author (s) Year } & \multicolumn{1}{c|}{ Definition } \\
\hline Dick and Basu (1994) & $\begin{array}{l}\text { Studies into loyalty conducted from the viewpoint of effective and manifest } \\
\text { behavior that creates repurchase or from attitude perspective }\end{array}$ \\
\hline Jones and Sasser (1995) & $\begin{array}{l}\text { Customer loyalty has two types. First, long-run genuine loyalty that is the } \\
\text { result of customer loyalty and customers will not change to other options, } \\
\text { and the other is short-run loyalty in which the customer changes to other } \\
\text { options if they find better services and products. }\end{array}$ \\
\hline
\end{tabular}




\section{International Advanced Research Journal in Science, Engineering and Technology}

Vol. 6, Issue 3, March 2019

\begin{tabular}{|l|l|}
\hline $\begin{array}{l}\text { Zeithaml, Berry, } \\
\text { and Parasuraman (1996) }\end{array}$ & $\begin{array}{l}\text { Loyal customers have high level of purchase intention, are not price } \\
\text { sensitive, feedback to company (complain behavior internally), conduct } \\
\text { more business (no switch and purchase frequently) }\end{array}$ \\
\hline Gremler and Brown (1996) & $\begin{array}{l}\text { Loyalty is the extent to which customer's show repurchase behavior from } \\
\text { suppliers, have positive attitudes about those providers and assume using } \\
\text { only this product when their need rises }\end{array}$ \\
\hline Oliver (1997, 1999); & $\begin{array}{l}\text { Loyal customers are highly committed to re-patronize or consistently } \\
\text { repurchase a service or product in future, regardless of situational impacts } \\
\text { and marketing attempts that can result in switching (p.392). }\end{array}$ \\
\hline Gil-Saura, (2008) & $\begin{array}{l}\text { Loyalty is known as a dedication on the part of the customer to maintain } \\
\text { relationships and is devoted to continuous purchase of a service or product. }\end{array}$ \\
\hline $\begin{array}{l}\text { Hennig-Thurau, Gwinner and } \\
\text { Gremler (2002) }\end{array}$ & $\begin{array}{l}\text { Customer loyalty is a repurchase behavior over time as a result of marketing } \\
\text { attempts to maintain current customers. }\end{array}$ \\
\hline Reichheld and Detrick, (2003) & $\begin{array}{l}\text { Customer loyalty is known as a strategy which provides mutual advantages } \\
\text { for both supplier and customer. }\end{array}$ \\
\hline $\begin{array}{l}\text { Jamal and Nastasiadou (2009); } \\
\text { Ganesh et al.,(2000); } \\
\text { Kim et al., (2007); Ou, (2011) }\end{array}$ & $\begin{array}{l}\text { Customer loyalty is known as a commitment to consistently re-patronize or } \\
\text { repurchase a preferred product in future. }\end{array}$ \\
\hline
\end{tabular}

\section{a. The Relationship between Service Quality and Customer Loyalty}

The definition of service quality revolves around the idea that it is the result of the comparison that customers make between their expectations of a service and their perception of the way the service has been performed [5]. Service quality is founded on a comparison between what the customer feels should be offered and what is provided [6] If the customer's expectations are met or exceeded, then the company is perceived to be offering higher service quality. But if on the other hand, the expectations of the customers are not met, the company is on its way only to face displeased and hostile customers, which in turn leads to defection to competitors. The actual quality of service is difficult to define [2]. but researchers have reached a consensus that service quality should be defined and measured from the customer's perspective [10].

\section{b. Corporate Image and Customer Loyalty}

A good corporate image stimulates purchase by simplifying decision procedures for customers. A strong brand can deliver for a company market leadership, a stable or sustainable competitive advantage, international reach, a platform from which to expand activities and long-term profit [11] The common link between image and satisfaction is perceived quality [12] For consumers brands are vital because they provide them of the product maker and thus allow consumers assign responsibility to a particular manufacturer or distributor. A good corporate image for high quality means 15 more customers, fewer dissatisfied customers and invariably, increases in profits which put the organization on a favourable competitive advantage. Brands also ease the consumers' decisions of which product/brand to use [21]. If the consumers can recognize or recall a brand (brand awareness) it is more likely that they will also use a product of that certain brand.

\section{c. Brand Image and Customer Loyalty}

A brand has been defined differently by different scholars. According to Wu (2011), a brand is a distinguishing name and/or symbol such as logo, trademark, or package design intended to identify the goods or services of either one seller or a group of sellers, and to differentiate those goods or services from those of competitors. The brand reflects the complete experience consumers have with products and protects both the customer and the producer from competitors who would attempt to provide products that appear to be identical [22].

\section{d. Perception of Value and Customer Loyalty}

A positive perception of value may bring customers back to make another transaction [18]. When customers believe they are being treated fairly in an exchange, they will be satisfied with the transaction if their outcome-to-input ratio is in 13 some sense adequate [15]. [20] pointed out that quality, price, and company or brand image were three factors that comprise the customer value package. In other words, customers will make an explicit comparison between what they give and what they get. The positive relationship between equity and satisfaction was supported in the literature [19]. However, customers expect prices to be lower in an online store than in a traditional sales channel [24]. They may expect to get more value from an online store than from a physical store. 


\section{International Advanced Research Journal in Science, Engineering and Technology}

Vol. 6, Issue 3, March 2019

\section{e. EFFECTS OF CUSTOMER SATISFACTION ON CUSTOMER LOYALTY}

Customer satisfaction has been considered the essence of success in today's highly competitive banking industry [12]. Customer satisfaction is generally understood as the satisfaction that a customer feels when comparing his preliminary expectations with the actual quality of the service or product acquired. In other words, customers are typically concerned with the value and quality of the product or service they receive [23]. Satisfaction is a psychological construct that form the basis upon which the evaluation of the quality of a product or service is made [16].

\section{DISCUSSION}

From the findings of the study it can be concluded that quality of service plays a crucial role in influencing customer loyalty hence the need for all bank employees to practice courtesy all the time. When the products and services are marketed the customers understand well the importance of that product and get the urge to embrace the product while engagement in corporate social responsibilities improves the customer loyalty since one individual works hand in hand with other members, in order to improve the work output in the company. However, banks face challenges to retain their customers hence need to come up with unique strategies to attract and retain their customers so that they are not tempted to move to other banks. At the same time there is need for the manager and other employees to budget on the costs of keeping their customers and keep track on the needs of the customers depending on seasons. Other customers however keep on over demanding for the services therefore employees need to understand them and educate them on the services provided by the bank. The employee sometimes also lacks the necessary knowledge in maintaining customer loyalty therefore training should be provided to the employees from the onset of the attachment so that they can clearly understand how to keep the customers loyal. When the customers, employees and employers are satisfied, harmony is prone to manifest which improves the general image of the bank. It is also clear that when the image of the bank is improved, both the customers and the employees will market the bank hence customers will come to the bank.

\section{CONCLUSION}

In terms of customer loyalty, it can be concluded that the reputation, quality, reliability are factors that positively influence customers. For this determination, a survey-based questionnaire was used and results were compared with international banking industry. However, it is found that there is a strong correlation, positive and significant among all three factors related to customer loyalty. On the other hand, a high proportion of respondents thought the quality of domestic banks is higher than that of foreign banks. The results of this chapter support the authors' expectations and accepted assumptions. The four variables, loyalty, satisfaction, retention and customer confidence that contribute to the development of customer loyalty programs represent important directions that contribute to competitiveness and maintenance of the banks in the banking industry.

\section{REFERENCES}

[1]. Bolton R. N., Drew J. H. (1991), A Multistage Model of Customers' Assessments of Service Quality and Value, Journal of Costumer Research, 17.375-84.

[2]. Chang, T. Z., Wildt, A. R. (1994), Price, Product Information, and Purchase Intention: An Empirical Study, Journal of the Academy of Marketing Science. 22 (1).16-27.

[3]. Cronin J. J., Brady, M. K., Hult G. T. M. (2000), Assessing the Effects of Quality, Value and Customer Satisfaction on Costumer Behavioral Intentions in Service Environments, Journal of Retailing. 76 (2), 193-218.

[4]. Duman T., Yagci M. İ. (2006), Süpermarket Müşterilerinin Devamlı Alişveriş Niyetlerini Etkileyen Faktörler: Bir Model Denemesi, METU Studies Development. 33:87-116.

[5]. Dick A., Basu K., (1994), Customer Loyalty: Toward an Integrated Conceptual Framework. Journal of the Academy of Marketing Science.22, 99-113.

[6]. Grewal D., Monroe K. B., Krishnan R. (1998), The Effects of Price- Comparison Advertising on Buyers' Perceptions of Acquisition Value, Transaction Value and Behavioral Intentions, Journal of Marketing.62.46-59.

[7]. Jones Thomas O., Sasser Earl W. Jr. (1995), Why Satisfied Customers Defect, Harvard Business Review,88-99.

[8]. Okumuş A., Temizler Z., (2006), Süpermarket Müşterilerinin Mağzaya Olan Bağımlılık Derecelerine Göre Pazar Bölümlerinin Tanımlanması Ve Bölümler Arasındaki Farklılıkların Incelenmesi, Yönetim. 17:54, 46-61.

[9]. Rhee J., Bell D.R. (2002), The Inter-Store Mobility of Supermarket Shoppers, Journal of Retailing.78.225-237.

[10]. Ruyter K., Wetzels M., Bloemer, J. (1998), On the Relationship Between Perceived Service Quality, Service Loyalty and Switching Costs, International Journal of Service Industry Management. 9 (5).436-53.

[11]. Sirohi N., Mclaughlin E.W., Wittink D.R. (1998), A Model of Costumer Perceptions and Store Loyalty Intentions for a Supermarket Retailer, Journal of Retailing. 74(2).223-245.

[12]. Topcu, Y., Uzundumlu, A. S. (2009), Analysis of Factors Affecting Customer Retailer Loyalty in The Turkish Food Market: The Case Study of Erzurum, Italian Journal of Food Science, 21 (2).157-169.

[13]. Recknagel, F., Orr, P. T. and Cao, H. (2014). Inductive reasoning and forecasting of population dynamics of Cylindrospermopsis raciborskii in three sub-tropical

[14]. Eshghi, A., Haughton, D., Topi, H., 2007. Determinants of customer loyalty in the wireless telecommunications industry. Telecommun. Policy 31, 93-106. 


\title{
International Advanced Research Journal in Science, Engineering and Technology
}

\author{
Vol. 6, Issue 3, March 2019
}

[15]. Jay Kandampully, Tingting (Christina) Zhang, Anil Bilgihan, (2015) "Customer loyalty: a review and future directions with a special focus on the hospitality industry", International Journal of Contemporary Hospitality Management, Vol. 27 Issue: 3, pp.379-414, https://doi.org/10.1108/IJCHM-03-2014-0151

[16]. Hari Govind Mishra, Piyush Kumar Sinha, Surabhi Koul, (2017) "Customer dependence and customer loyalty in traditional and modern format stores", Journal of Indian Business Research, Vol. 9 Issue: 1, pp.59-78, https://doi.org/10.1108/JIBR-12-2015-0126

[17]. Man Zhang, Janet Hartley, (2018) "Does guanxi influence product performance and customer loyalty?", Journal of Asia Business Studies, Vol. 12 Issue: 3, pp.233-252, https://doi.org/10.1108/JABS-06-2016-0082

[18]. Mirza Tabrani, Muslim Amin, Ahmad Nizam, (2018) "Trust, commitment, customer intimacy and customer loyalty in Islamic banking relationships", International Journal of Bank Marketing, Vol. 36 Issue: 5, pp.823-848, https://doi.org/10.1108/IJBM-03-2017-0054

[19]. Achchuthan Sivapalan, Charles Jebarajakirthy, (2017) "An application of retailing service quality practices influencing customer loyalty toward retailers", Marketing Intelligence \& Planning, Vol. 35 Issue: 7, pp.842-857, https://doi.org/10.1108/MIP-09-2016-0178

[20]. André de Waal, Béatrice van der Heijden, (2016) "Increasing customer loyalty and customer intimacy by improving the behavior of employees", Journal of Strategy and Management, Vol. 9 Issue: 4, pp.492-510, https://doi.org/10.1108/JSMA-06-2015-0045

[21]. Maryam Keshvari, Firoozeh Zare Farashbandi, Ehsan Geraei, (2015) "Modelling influential factors on customer loyalty in public libraries: a study of West Iran", The Electronic Library, Vol. 33 Issue: 4, pp.810-823, https://doi.org/10.1108/EL-10-2013-0185

[22]. Vinita Kaura, Ch. S. Durga Prasad, Sourabh Sharma, (2015) "Service quality, service convenience, price and fairness, customer loyalty, and the mediating role of customer satisfaction", International Journal of Bank Marketing, Vol. 33 Issue: 4, pp.404-422, https://doi.org/10.1108/IJBM04-2014-0048

[23]. Tsu-Wei Yu, Lu-Ming Tseng, (2016) "The role of salespeople in developing life insurance customer loyalty", International Journal of Retail \& Distribution Management, Vol. 44 Issue: 1, pp.22-37, https://doi.org/10.1108/IJRDM-06-2014-0074

[24]. Ingy Shafei, Hazem Tabaa, (2016) "Factors affecting customer loyalty for mobile telecommunication industry", EuroMed Journal of Business, Vol. 11 Issue: 3, pp.347-361, https://doi.org/10.1108/EMJB-07-2015-0034

[25]. Elisabetta Savelli, Marco Cioppi, Federica Tombari, (2017) "Web atmospherics as drivers of shopping centres' customer loyalty", International Journal of Retail \& Distribution Management, Vol. 45 Issue: 11, pp.1213-1240, https://doi.org/10.1108/IJRDM-07-2016-0120

[26]. Gabriel Sperandio Milan, Luiz Antonio Slongo, Luciene Eberle, Deonir De Toni, Suélen Bebber, (2018) "Determinants of customer loyalty: a study with customers of a Brazilian bank", Benchmarking: An International Journal, Vol. 25 Issue: 9, pp.3935-3950, https://doi.org/10.1108/BIJ-08-2017-0231

[27]. Mirza Tabrani, Muslim Amin, Ahmad Nizam, (2018) "Trust, commitment, customer intimacy and customer loyalty in Islamic banking relationships", International Journal of Bank Marketing, Vol. 36 Issue: 5, pp.823-848, https://doi.org/10.1108/IJBM-03-2017-0054. 